\title{
Trace metals characterization in environmental media: A case study of cement production area Ewekoro, southwest, Nigeria
}

\author{
Majolagbe A. O.*, Yusuf, K. A., Duru, A. E. \\ Dept. of chemistry, Lagos state University, Lagos, Nigeria
}

Email address:

abdulmajss@gmail.com (Majolagbe A. O.)

\section{To cite this article:}

Majolagbe A. O., Yusuf, K. A., Duru, A. E. Trace Metals Characterization in Environmental Media: A Case Study of Cement Production Area Ewekoro, Southwest, Nigeria. American Journal of Environmental Protection. Vol. 3, No. 2, 2014, pp. 83-89.

doi: 10.11648/j.ajep.20140302.17

\begin{abstract}
Environmental quality deterioration resulting from increase in the level of potentially toxic metals is becoming more pronounced, thus raising the question on safety status of our environment. Impact assessment and characterization of trace metals in the environmental media including groundwater, top soils, and tree barks in the vicinities of West African Portland Cement Company factory mill, Ewekoro, Ogun State, Nigeria was undertaken. The environmental samples were analysed for trace metals employing flame atomic absorption spectrometry (FAAS). The concentration of $\mathrm{Cu}, \mathrm{Cd}$ and $\mathrm{Fe}$ detected in the groundwater ranged between $0.026-0.082,0.0038-0.004$ and $0.003-0.035(\mathrm{mg} / \mathrm{L})$ respectively. A decrease order in the level of metals level observed in the top soil is $\mathrm{Fe}>\mathrm{Pb}>\mathrm{Ni}>\mathrm{Cr}>\mathrm{Cu}>\mathrm{Cd}$, while that of tree barks samples is $\mathrm{Fe}>$ $\mathrm{Cu}>\mathrm{Cr}>\mathrm{Pb}>\mathrm{Ni}>\mathrm{Cd}$. The saturated index (SI) obtained (through phreqC model) of the groundwater samples showed saturated to undersaturated with respect to $\mathrm{CdSO}_{4}$ and $\mathrm{FeSO}_{4}: 7 \mathrm{H}_{2} \mathrm{O}$, while SI was saturated to supersaturate with respect to $\mathrm{CdCO}_{3}$ and $\mathrm{FeCO}_{3}$. Quality indices employed in analyzing soil data include enrichment factor, contamination factor and pollution load index. There is a buildup of trace metals in the environment (soil) particularly $\mathrm{Pb}$. The levels of metals investigated are within the threshold limit set by the WHO health-based guideline for drinking water. Significant correlations were found to exist between $\mathrm{Cd}$ and $\mathrm{Ni}, \mathrm{Cr}$ and $\mathrm{Fe}$ both in the tree bark and top soil samples, suggesting common source.
\end{abstract}

Keywords: Ewekoro, Enrichment Factor, Pollution Load Index, Cement, Impact Assessment, Phreeqc

\section{Introduction}

The level of industrial activities in a nation is a mark of its development. The planning of such is with objectives such as: economic benefits, creating employment, thereby reducing crime rate and poverty as well as improving general standards of living. However, these industrial activities are not without adverse consequences on the environment. Therefore, setting up an industry is often guided by standards so as to make the environment safe and sustainable. These standards include majorly, establishment of Environmental Impact Assessment (EIA) on the proposed industrial activity. Among other things, the EIA addresses possible environmental consequences of a project and recommends ways to mitigate against such condition. The levels of heavy metals in the environment has been on increase in the last few decades due to various anthropogenic activities, notably manufacturing and mining activities[1], as well as the use of synthetic products such as pesticides, paint, and batteries [2] . The industrial processes are also responsible for the wider diffusion of these elements in the environment [3]. Heavy metal is a term used for a wide group of metallic elements with density equal or greater than $5 \mathrm{~g} / \mathrm{cm} 3$. Such metals include cadmium, copper, chromium, lead, nickel and iron. They are trace elements when their occurrences in the environment is less than 0.02 part per million. They are generally associated with pollution and toxicity [4]. Trace metals occur naturally in soils (but rarely at toxic levels), sedimentary deposits and water bodies; therefore, there are normal background concentrations of these metals. These metals also found their way (anthropogenic sources) into soils, vegetations, water bodies and sediments via airborne particulate matter in the form of dust and vehicular emission. Many researchers [5,6] have reported elevated concentration of trace metals from roadsides, food waste, lubricating oils, sewage systems among other sources. Cement production 
is characterized by particulate air pollutants, which are produced during blasting of raw materials, grinding of cement, packaging or loading of finished cement. Some of the numerous components of cement include alumina, silica, polychlorinated dioxins, furans and heavy metals such as mercury, antinomy, calcium, zinc, lead, chromium arsenic and manganese, majority of which are potentially harmful elements (PHEs) to the biotic components of the environment [7]. Metallic elements such as $\mathrm{Fe}, \mathrm{Zn}, \mathrm{Mo}, \mathrm{Cu}$, $\mathrm{Co}$ and $\mathrm{Cr}$ are known to be essential elements. They play vital roles in various metabolic activities in plants and animals at trace level, however, at high concentration, they may be potentially toxic [6]. Copper is an essential substance to life, it is a part of several enzymes including Tyrosinase which helps in formation of melanin pigment. It also helps in utilization of iron. Copper normally occurs in drinking water from copper pipes, as well as from additives designed to control algal growth, however, at high concentration, it can cause anemia, liver and kidney damage as well as stomach and intestinal irritation. Excessive intake of $\mathrm{Cu}$ may also cause death with symptoms such as hypertension, coma and jaundice [8]. People with Wilson's disease are at greater health risk from overexposure to copper. Deficiency of $\mathrm{Cu}$ is also dangerous, characterized by microcytic anemia resulting from defective hemoglobin synthesis. Heavy metals such as $\mathrm{Pb}, \mathrm{Cd}$ and $\mathrm{Ni}$ are toxic even at trace level and they adversely affect life under varying health conditions. For instance, cadmium, an inevitable bye product of Zinc refining is acutely toxic, with chronic exposure. It affects the kidney and it is associated with an increased incidence of cancer of the prostate. Cadmium may interfere with the metallothionein's ability to regulate zinc and copper concentrations in the body system. Metallothionein is a protein that binds to excess essential metals to render them unavailable, when cadmium induced metallothionein activity; it binds to copper and zinc disrupting the homeostasis levels. Lead $(\mathrm{Pb})$ is one of the most abundant, ubiquitously distributed toxic elements. Lead and its organic compound are accumulative toxins which enter the body system through inhalation of dust, fumes and vapour or by ingestion [9]. Lead contamination results from mining and smelting activities, lead-containing paints, paper and pulp, gasoline, explosives, and the im proper disposal of municipal sewage sludge containing lead. In animals, lead at high concentration adversely affects the reproductive, nervous, immune, cardio-vascular, and other systems. Growth and photosynthetic processes of plants are affected by $\mathrm{Pb}$ through inhibition of enzyme activities and alterations in membrane permeability leading to water and mineral imbalances [10]. $\mathrm{Pb}$ is actively pathogenic to brain development in children [11]. Lead, when in high concentration, substitute for calcium in the bone. Children are especially susceptible to this form of lead poison because developing skeletal systems require high levels of calcium.

The toxicity of heavy metals in aquatic environment is largely a function of water chemistry and sediment composition in the water body system. Slightly elevated metal levels in natural waters may cause morphological change in tissues, suppression of growth and development, poor swimming performance, change in enzyme activity and reproduction in aquatic organisms. Heavy metal pollution in soil has been assessed by Liu [11] using pollution index (Pi), which was obtained as a ratio of metal concentration in contaminated soil to its concentration in natural background sample. Toxicity of heavy metals is related to their existing species; hence, speciation of these cations is increasingly attracting more attentions [1]. The soil, plants and water in the neighborhood of the cement company are being threatened by pollution from the company. Prevention is still the best method to protect the environment from contamination of heavy metal, more so, that cleaning of contaminated soil is difficult and expensive. This study therefore, investigated the concentration levels of potentially harmful toxic metals in groundwater, tree barks and top soil in the vicinities WAPCO of cement production. It will help in establishing the safety level of the environment and a data base for further studies.

\section{Materials and Methods}

\subsection{Study Area}

Ewekoro works, one of the mills of West African Portland Cement Company (WAPCO) is situated in Ewekoro town in Ogun state. Ewekoro town is a sleepy neighboring town to Papalanto, a name known for Sugar cane plantation. It lies between latitude $6^{0} 53^{\prime}$ North, and longitude $3^{0} 14^{\prime}$ East. It is bounded in the north by Abeokuta, in the east by Obafemi Owode, in the West by Yewa South and by Ado-Odo-Ota in the South. The geology of Ogun State covering Ewekoro town, comprises of sedimentary rocks which underlie approximately three quarters and the remaining one quarter covered by basement rocks [12]. The sedimentary rocks of Ogun State consist of Ewekoro formation and Abeokuta formation. The Ewekoro formation is fossil ferrous and consists of economic deposits of lime stones that is presently quarried by WAPCO [13].

\subsection{Samples and Sampling Techniques}

A total number of fifteen (15) groundwater samples, ten (10) top soil samples $(0-15 \mathrm{~cm})$ and ten (10) plant bark samples were collected. The sampling locations were carefully chosen after a pre-sampling site survey. Plastic containers for groundwater samples were thoroughly washed with detergent, rinsed with water and then with distilled water before soaking with $10 \%$ of HNO3 overnight [14]. The containers were finally rinsed with deionized water prior sample collection. Groundwater samples from shallow wells in the villages within the vicinity of Ewekoro cement works were collected into two different plastic containers; $1.5 \mathrm{~L}$ and $0.5 \mathrm{~L}$ for Physico-chemical and metal analyses respectively. The $0.5 \mathrm{~L}$ water was spiked with 1.0 $\mathrm{ml}$ of concentrated HNO3 (Analar) so as to preserve the samples. The soil sampling spots were cleaned of debris and composite top soils with depth between $0 \mathrm{~cm}$ and $15 \mathrm{~cm}$ 
were collected at different selected sampling points to provide a representative coverage of the study site using soil auger and transferred into clean acid-washed polyethylene bags. This layer of soil constitutes the absorption zone of the roots of most food crops such as cassava (Manihot esculenta) and sugar cane Saccharum officinales ) grown within the Ewekoro town, the host of West African Portland Cement Company (WAPCO) mill, southwestern Nigeria. Composite controls sample for top soil were collected from Ifo and Oju -ore (about $5 \mathrm{~km}$ and $20 \mathrm{~km}$ respectively from the study area) so as to confirm the consistency in reduction of metal concentration with distance away from the study site. Composite tree bark samples were collected at a height of $3 \mathrm{~m}$ above the ground level [15] using clean acid-washed stainless knife and further washed after each sampling with $10 \% \mathrm{HNO}_{3}$ to avoid cross contamination. The barks were designated $\mathrm{P}_{1}-\mathrm{P}_{6}$. Control for bark samples was collected from Oju -ore and placed in clean acid washed polyethylene bags. All samples were transported to the laboratory, the water samples were stored in the refrigerator at $4^{0} \mathrm{C}$, top soils and plant barks were air dried at room temperature until analysis.

\subsection{Sample Chemical Analyses}

\subsubsection{Hydrochemistry}

The $\mathrm{pH}$ and temperature of the groundwater samples were determined in-situ. The $\mathrm{pH}$ was carried out with $\mathrm{pH}$ meter (pHep HANNA HI 98107) and temperature was estimated using thermometer. Determination of alkalinity was done titrimetrically [16], Total Hardness by complexomertry [16], Total suspended solids, Dissolved solids and Total solids by gravimetry [16, 17], Chloride by Mohr's method [16] and Sulphate by turbidimetric method [16]. Determination of cations: $\mathrm{Cr}, \mathrm{Pb}, \mathrm{Cd}, \mathrm{Ni}, \mathrm{Fe}$, and $\mathrm{Cu}$ was also carried out, in line with methods of chimuka et al., (2005), employing Flame Atomic Absorption Spectrophotometer.( (Buck scientific 210 VGP model).

\subsubsection{Ph of the Top Soil Samples}

The $\mathrm{pH}$ of top soils samples was determined using sieved soil samples. $2 \mathrm{~g}$ of each top soil samples was weighed into clean beaker; deionised water was added gradually to form a slurry solution and the mixture was allowed to stand for 30minutes with occasional stirring using a glass rod. The $\mathrm{pH}$ was then taken using calibrated $\mathrm{pH}$ meter (pHep HANNA HI 98107).

\subsubsection{Metal Content of the Soil Samples}

The top soil samples were air dried and pulverized using clean laboratory mill, then sieved through 500 um aperture. $2.0 \mathrm{~g}$ of pulverized soil sample was taken in a $250 \mathrm{ml}$ beaker and moistened with few drops of deionized water to prevent loss by spattering during digestion. The sample was digested with $10 \mathrm{ml}$ of concentrated $\mathrm{HNO}_{3}$ on a hotplate in a fume cupboard to volume of about $3 \mathrm{ml}$. The residues obtained were further digested with a mixture of concentrated acids containing $5 \mathrm{ml}$ each of concentrated $\mathrm{HCl}, \mathrm{HNO}_{3}$ and
$\mathrm{HC} \mathrm{O}_{4}$ at room temperature for 10 minutes until the solution was brought to a final volume of about $5 \mathrm{ml}$ on a hot plate in fume cupboard. The digest was allowed to cool and filtered into a $100 \mathrm{ml}$ volumetric flask using whatman No.1 filter paper. It was then made up to mark with the deionized water. The control samples were also treated with the same procedure as above.

\subsubsection{Metal Content of Yhe Tree Bark Samples}

The tree bark samples were air dried at room temperature, crushed with clean laboratory mill and then sieved through $500 \mathrm{um}$ aperture to obtain fine bark particles. $2.0 \mathrm{~g}$ of each of tree bark sample was weighed into $250 \mathrm{ml}$ beaker, a mixture of $20 \mathrm{ml} \mathrm{HNO}_{3}$ and $8 \mathrm{ml} \mathrm{HClO}_{4}$ was used to digest the samples on a hot plate in a fume hood to a final volume of $5 \mathrm{ml}$. The digest was cooled, drops of demonized water were added and the solution filtered into a volumetric Flask using whatman No.1 filter paper. The flask was then made up to the $100 \mathrm{ml}$ mark with demonized water. The same procedure was carried out on the control tree bark samples. All digest (Soil, tree barks and groundwater) was analyzed for heavy metals using flame atomic absorption spectrophotometer (Buck 210 VGP). All analyses were duplicated to test for reliability of the method and instrument. Recovery study on groundwater samples was also carried out.

\subsection{Statistical Analysis}

Descriptive statistics of water quality data generated was using mean and standard deviation. Correlations coeficiency was performed in a pair wise fashion employing Pearson correlation procedure, so as to establish any possible chemical association within the various quality parameters determined and probable source of pollution. Clustered bar chart was also produced to show element concentration in top soil, tree bark and groundwater. Some quality indices were also employed to further analyse the result obtained from the study:

$i$. The enrichment factor $(E F)$. The EF helps more importantly to differentiate between metals originating from anthropogenic activities and those from natural processes, as well as assessing the degree of anthropogenically influence [18]. The EF is calculated by

$$
\mathrm{EF}=\left[\mathrm{C}_{\text {metal }} / \mathrm{C}_{\text {normalizer }}\right] \text { soil } /\left[\mathrm{C}_{\text {metal }} / \mathrm{C}_{\text {normalizer }}\right] \text { control }
$$

Where $\mathrm{C}_{\text {metal }}$ and $\mathrm{C}_{\text {normalizer }}$ are concentration of heavy metals and normalizer in soil samples and control samples respectively. The normalizer in this study is element iron.

ii. The pollution load Index (PLI). PLI helps to evaluate the extent to which the study area under investigation is polluted with metals. Various methods of calculation have been reported in literatures by various researchers. [19, 20, 21]. The PLI is calculated as follows:

$$
\mathrm{PLI}=\left(\mathrm{CF}_{1} \times \mathrm{CF}_{2} \times \mathrm{CF}_{3} \times \ldots \mathrm{CF}_{\mathrm{n}}\right)^{1 / \mathrm{y}}
$$

Where $\mathrm{CF}$ is contamination factor and $\mathrm{y}$ is the number of metals analysed. 


\section{Results and Discussion}

The mean values of physicochemical parameters and trace metals in groundwater analysed were compared with various international standards such as World Health Organisation (WHO), United State Environmental Agency (USEPA), National Standards for drinking water Quality (NSDWQ) and National Environmental Standards and Regulation Enforcement Agency (NESREA) as shown in Table 1.0. The concentration of most of the quality parameters determined are within the permissible limits. Forty two percent (42\%) of the groundwater samples analyzed had TDS values higher than the NESREA and NSDWQ acceptable limits of 100 $\mathrm{mg} / \mathrm{L}$ in drinking water. Although, the mean chloride value was below allowable limits of $250 \mathrm{mg} / \mathrm{L}$ in drinking water, about $64.3 \%$ of the water samples studied was with chloride values higher than $40.0 \mathrm{mg} / \mathrm{L}$ suggesting input from salt water intrusion from neighboring water body.

All trace metals analyzed are also below permissible limit of various regulatory bodies employed except Cadmium $(0.004 \mathrm{mg} / \mathrm{L})$ which was higher than the WHO allowable limit of $0.003 \mathrm{mg} / \mathrm{L}$. Cadmium is one of the pollutant of priority in groundwater assessment and monitoring by environmental protection agency [22]. The average daily intake of cadmium is estimated as $0.15 \mu \mathrm{g}$ from air and 1.0 $\mu \mathrm{g}$ from water. Although Cd is eventually excreted, however, it is biopersistent, and once absorbed by an organism, remains resident over decades in human system. The major sources of $\mathrm{Cd}$, are atmospheric deposition and through fertilizer application in agricultural soil. The level of other Physico- chemical parameters investigated further reveal the portability of the groundwater in the study area. Toxic metals from cement factories are capable of altering chemical loads of water, thereby affecting the quality of water supply of the local community for drinking and irrigation purposes [7]. The groundwater studied can be classified based on the concentration of total dissolved solids as a fresh moderately hard. The alkalinity level of water under investigation belongs to a class in which alkalinity hazard require proper treatment before consumption [23]. A very weak negative correlation was observed in the matrix of metals in groundwater. This indicates possible varying anthropogenic sources of metals in the aquifer.

PhreeqC, a computer program was used to generate saturation index (SI), which helps in evaluating degree of equilibrium between water and minerals. Changes in saturation state are useful to distinguish different stages of hydrochemical evolution and help identify which geochemical reactions are important in controlling water chemistry [24]. A saturation index less than zero, indicates that the groundwater is undersaturated with respect to that particular mineral. Such a value could reflect the character of water from a formation with insufficient amount of the mineral for solution or short residence time. An index greater than zero, specifies that the groundwater being supersaturated with respect to the particular mineral phase and therefore incapable of dissolving more of the mineral. The SI results of this study shows that groundwater samples were saturated to undersaturated with respect to $\mathrm{s}$ $\mathrm{Cd}(\mathrm{OH}) 2$, CdSO4, Melanterite (FeSO4:7H2O), while samples were saturated to supersaturated with respect to Otavite $\left(\mathrm{CdCO}_{3}\right)$ and Siderite $\left(\mathrm{FeCO}_{3}\right)$. The mean values of

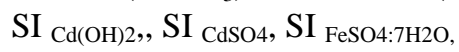

$\mathrm{SI}_{\mathrm{CdCO} 3}$ and $\mathrm{SI}_{\mathrm{FeCO} 3}$ are $-6.28,-8.65,-6.16,1.31$ and 0.65 respectively.

\subsection{Soil Analyses}

The $\mathrm{pH}$ of the soil samples analyzed ranged from 7.6 to 8.4 with average value of 8.1 (Table 2.0 ), which is slightly basic. $\mathrm{pH}$ plays an important role in metal bioavailability, toxicity and leaching capacity of soil to surrounding areas [6]. Trace metals are known to form complexes with organic matter and this influences their mobility in the soil, Metals readily leach out in acidic $\mathrm{pH}$ [25].The results of the concentration of the trace metals measured in top soil samples are given in Table 2.0.

The levels of $\mathrm{Fe}, \mathrm{Ni}, \mathrm{Cr}$ and $\mathrm{Cd}$ are higher in the soil samples in the vicinities of cement factory than in the controls samples. This may indicates the impact of the production activities on the environment. Fe was having the highest means concentration of $91.6 \pm 0.3 \mu \mathrm{g} / \mathrm{g}$ of all the metals analyzed. The high concentration of the metal has been well documented in literatures [26, 27].

The mean values for $\mathrm{Cu}$ and $\mathrm{Pb}$ in controls sample were slightly higher than the Ewekoro samples, suggesting the possibility of other sources, which include automobile emission, urban surface run off and bush burning. $\mathrm{Pb}$ is particularly considered to be an air pollutant that readily sojourn a long distance through dispersion from source of emission [28], therefore, cement factory (activities) could be a remote source of theses metals. This assertion is further corroborated trend of metals concentration in the two control locations which reflect the concentration of metals as a function of increase in distance from the Ewekoro factory. Results obtained were subjected to correlation coefficient (Table 3.0). Cr was found to have significant correlation ( $\mathrm{p}$ $<0.05$ ) with $\mathrm{Ni}, \mathrm{Pb}, \mathrm{Cu}$ and $\mathrm{Fe}$, strong correlation was also observed between $\mathrm{Cu}$ and $\mathrm{Pb}, \mathrm{Pb}$ and $\mathrm{Ni}, \mathrm{Cd}$ and $\mathrm{Ni}$ and also between $\mathrm{Ni}$ and $\mathrm{Fe}, \mathrm{Mg}$. this indicated that all these metals are probably from the same source (cement works).

The EF and CF values are shown in Table 4.0. Based on Sutherland [18] classification, all enrichment factor values obtained show minimal enrichment of respective metals except $\mathrm{Pb}$ with moderate enrichment. However, contamination factor showed a clearer picture with copper and lead having low contamination in the studied soil, while chromium, cadmium, nickel and iron displayed moderate impact on the environment. The calculated PLI for the study location is 0.86 , implying non -contamination. This shows human friendly state of the soil environment under consideration. This goes further to imply that the pollutants generated from the cement production might be in dispersed form. 


\subsection{Tree Bark Analyses}

The mean value of the metals investigated in tree bark samples is shown in Table 5.0. The results obtained showed more abundance of $\mathrm{Mg}$, compared to other metals analyzed, with cadmium having the lowest concentration. The surface structure of a tree bark has considerable influence on the rate of accumulation of metals. Literatures of past related works have established that, a tree bark, with a coarse, rough surface more readily absorb atmospheric pollutants more than a smooth surface [28]. Bark is exposed to pollutants either directly from the atmosphere or from stem flow. Level of bark metals in this study was found to be lower than the normal toxicity range given by Bowen [29] as shown in Table 5.0. Generally, all the environmental samples analyzed showed considerable level of $\mathrm{Mg}$. The high levels of $\mathrm{Mg}$ might as a result of contributions from other sources such as agricultural run-off and geological formation of the area. $\mathrm{Mg}$ however shows weak correlation $(\mathrm{p}<0.05)$ with $\mathrm{Cr}, \mathrm{Cu}, \mathrm{Pb}$ and $\mathrm{Fe}$ in all the samples analyzed. Positive correlations were observed in $\mathrm{Ni}$ versus $\mathrm{Mg}$, $\mathrm{Ni}$ versus $\mathrm{Cr}, \mathrm{Mg}$ versus $\mathrm{Cd}$, $\mathrm{Pb}$ versus $\mathrm{Cd}$, and $\mathrm{Fe}$ versus $\mathrm{Pb}$ (Table 6.0), implying that these paired metals are from the same source probably (Cement works). Plants accumulate metals from the soil via their roots system and transport to other parts of the plant. They (Plants) can also accumulate metals from atmospheric deposition through folia absorption or its bark. Jarmo, [28] investigated uptake of $\mathrm{Cd}, \mathrm{Cu}, \mathrm{Ni}$ and $\mathrm{Pb}$ in air and soil by milfoil and barley, he however concluded that $\mathrm{Ni}$ and $\mathrm{Cd}$ content in the plants correlated with deposition and soil content. Although the concentrations of all the metals analyzed in the environment samples are within threshold limits, continuous accumulation may result to serious health problems. Deposition of these metals from cement on herbaceous plants and fruits crops can cause effects such as blocking leaves stomata, reduced number of plant leaf and reduction in vegetative growth and reproduction structure [7].

The use of tree bark as herbs and drug supplement, eating raw fruits without thorough washing appear as common practices particularly in Africa, these constitute direct route of metals to metabolic pathway of man [15]. Trace metals indeed play important roles in biochemical processes, being essential components of molecular structure, therefore, participate in processes such as enzyme regulation and gene expression. However, various toxic effects are induced at elevated level of trace metals.

\section{Conclusion}

This study presented the level and distribution of trace metals in environmental media (soil, groundwater and tree barks) in the vicinities of cement production area (WAPCO), Ewekoro, southwest, Nigeria. All the metals investigated were found present at contamination level in the three environmental media under consideration. The study reveals more of pollutants that are air bound than that of soil and water. Trace metal such as cadmium and iron were observed higher than the allowable limit in groundwater. This portends a serious health threat to the inhabitants of this community, whose groundwater is the main source of water for drinking and domestic needs. Although, the PLI value is implying human friendly status of the study location, but the EF is warning of the possible build up of metals particularly $\mathrm{Pb}$.

The continuous accumulation of these metals, if not checked could result in pollution status with possible lethal effect to both terrestrial and aquatic organisms within the environment and beyond. Hence, the need for strict compliance on environmental rules and regulation by the cement production factory, to ensure safety of man and the environment.

Table 1.0. Mean values of Physico-chemical parameters and trace metals in groundwater samples and some standards.

\begin{tabular}{ccccc}
\hline Parameters & $\begin{array}{c}\text { Experimental } \\
(\mathbf{m g} / \mathbf{L})\end{array}$ & $\begin{array}{c}\text { WHO[ } \\
\mathbf{3 0}] \\
(\mathbf{m g} / \mathbf{L})\end{array}$ & $\begin{array}{c}\text { NSDWQ[ } \\
\mathbf{3 1}] \\
(\mathbf{m g} / \mathbf{L})\end{array}$ & $\begin{array}{c}\text { USEPA } \\
{[\mathbf{3 2}]} \\
(\mathbf{m g} / \mathbf{L})\end{array}$ \\
\hline $\mathrm{Cd}$ & 0.004 & 0.003 & 0.01 & 0.005 \\
$\mathrm{Cr}$ & $\mathrm{Nd}$ & 0.05 & 0.05 & 0.05 \\
$\mathrm{Cu}$ & 0.054 & 2.0 & 1.0 & 1.3 \\
$\mathrm{Fe}$ & 0.02 & 0.3 & 0.3 & - \\
$\mathrm{Pb}$ & $\mathrm{Nd}$ & 0.01 & 0.01 & 0.01 \\
$\mathrm{Ni}$ & $\mathrm{Nd}$ & 0.02 & & - \\
$\mathrm{pH}$ & 7.0 & $6.5-8.5$ & $6.5-8.5$ & $6.5-8.5$ \\
Temperature ${ }^{\circ} \mathrm{C}$ & 28 & - & & - \\
$\mathrm{TSS}$ & 495 & - & & - \\
$\mathrm{TDS}^{2}$ & 421 & 1000 & 500 & - \\
$\mathrm{TS}^{-}$ & 917 & 1500 & & - \\
$\mathrm{Cl}^{-}$ & 57.2 & 250 & 250 & 100 \\
$\mathrm{SO}_{4}{ }^{2-}$ & 19.2 & 400 & 100 & 100 \\
Total Alkalinity & 180 & 100 & 100 & 100 \\
Total Hardness & 95.3 & 500 & - & - \\
\hline
\end{tabular}

$\mathrm{Nd}=$ not detected, TSS- total suspended solids, TDS - total dissolved solids, TS - total solids

Table 2.0. Level of trace metals concentration $(\mu \mathrm{g} / \mathrm{g})$ and $\mathrm{pH}$ of soil samples.

\begin{tabular}{|c|c|c|c|c|c|c|c|}
\hline Sample Code & $\mathrm{Cr}$ & $\mathbf{C u}$ & $\mathbf{P b}$ & Cd & $\mathbf{N i}$ & $\mathbf{F e}$ & pH \\
\hline Soil 1 & $0.56 \pm 0.01$ & $0.95 \pm 0.05$ & $2.01 \pm 0.01$ & $0.04 \pm 0.001$ & $0.67 \pm 0.03$ & $119 \pm 1.43$ & $7.80 \pm 0.01$ \\
\hline Soil 2 & $0.42 \pm 0.03$ & $0.10 \pm 0.45$ & $0.64 \pm 0.04$ & $0.01 \pm 0.002$ & $0.48 \pm 0.01$ & $120 \pm 1.97$ & $7.60 \pm 0.03$ \\
\hline Soil 3 & $0.11 \pm 0.02$ & $0.03 \pm 0.002$ & ND & ND & $0.08 \pm 0.002$ & $42.9 \pm 0.1$ & $8.00 \pm 0.03$ \\
\hline Soil 4 & $0.38 \pm 0.02$ & $0.11 \pm 0.01$ & $0.51 \pm 0.003$ & $0.02 \pm 0.003$ & $0.514 \pm 0.01$ & $125 \pm 2.51$ & $8.50 \pm 0.02$ \\
\hline Soil 5 & $0.54 \pm 0.01$ & $0.51 \pm 0.01$ & $1.75 \pm 0.01$ & $0.053 \pm 0.004$ & $0.78 \pm 0.02$ & $122 \pm 3.58$ & $8.20 \pm 0.02$ \\
\hline Soil 6 & $0.22 \pm 0.01$ & $0.04 \pm 0.003$ & $0.22 \pm 0.02$ & $0.01 \pm 0.001$ & $0.18 \pm 0.004$ & $32.0 \pm 1.7$ & $8.00 \pm 0.01$ \\
\hline Soil 7 & $0.48 \pm 0.03$ & $0.12 \pm 0.021$ & $0.57 \pm 0.010$ & $0.043 \pm 0.003$ & $0.461 \pm 0.001$ & $94.6 \pm 4.41$ & $8.30 \pm 0.01$ \\
\hline Soil 8 & $0.85 \pm 0.01$ & $0.20 \pm 0.01$ & $0.65 \pm 0.01$ & $0.031 \pm 0.004$ & $0.406 \pm 0.01$ & $3.00 \pm 0.12$ & $8.50 \pm 0.02$ \\
\hline Soil 9 & $0.16 \pm 0.05$ & $0.25+0.002$ & $1.00+0.01$ & $0.024+0.001$ & $0.441+0.002$ & $139+7.62$ & $8.30 \pm 0.03$ \\
\hline Soil 10 & $0.71 \pm 0.03$ & $0.21+0.01$ & $1.07+0.01$ & $0.051+0.002$ & $0.815+0.02$ & $120 \pm 2.3$ & $8.40 \pm 0.02$ \\
\hline
\end{tabular}




\begin{tabular}{|c|c|c|c|c|c|c|c|}
\hline Sample Code & $\mathrm{Cr}$ & $\mathbf{C u}$ & $\mathbf{P b}$ & Cd & $\mathbf{N i}$ & $\mathbf{F e}$ & pH \\
\hline Mean & $0.44 \pm 0.02$ & $0.27 \pm 0.06$ & $0.84 \pm 0.05$ & $0.03 \pm 0.002$ & $0.50 \pm 0.01$ & $91.6 \pm 3.30$ & $8.16 \pm 0.02$ \\
\hline Contr. 1 & $0.39 \pm 0.02$ & $0.58 \pm 0.09$ & $1.96 \pm 0.027$ & $0.027 \pm 0.003$ & $0.43 \pm 0.03$ & $88.1 \pm 2.05$ & $7.80 \pm 0.01$ \\
\hline Contr. 2 & $0.31 \pm 0.03$ & $0.49 \pm 0.03$ & $1.73 \pm 0.071$ & $0.02 \pm 0.002$ & $0.38 \pm 0.03$ & $86.2 \pm 2.2$ & $8.00 \pm 0.02$ \\
\hline Normal range in soil & $5-1500$ & $2-250$ & $2-300$ & $0.01-2.0$ & $5-500$ & $7-550$ & - \\
\hline
\end{tabular}

$\mathrm{ND}=$ not detected

Table 3.0. correlation coefficient matrix of metals in soil.

\begin{tabular}{cccccccc}
\hline & $\mathbf{C r}$ & $\mathbf{C u}$ & $\mathbf{P b}$ & $\mathbf{C d}$ & $\mathbf{N i}$ & $\mathbf{F e}$ & $\mathbf{M g}$ \\
\hline $\mathrm{Cr}$ & 1.0 & & & & & & \\
$\mathrm{Cu}$ & 0.6 & 1.0 & & & & & \\
$\mathrm{~Pb}$ & 0.7 & 0.9 & 1.0 & & & & \\
$\mathrm{Cd}$ & 0.5 & 0.2 & 0.4 & 1.0 & & & \\
$\mathrm{Ni}$ & 0.8 & 0.5 & 0.7 & 0.8 & 1.0 & & \\
$\mathrm{Fe}$ & 0.6 & 0.3 & 0.5 & 0.3 & 0.7 & 1.0 & \\
$\mathrm{Mg}$ & 0.2 & -0.3 & -0.02 & 0.4 & 0.6 & 0.4 & 1.0 \\
\hline
\end{tabular}

Table 4.0. Enrichment factor and contamination factor of metals in soil.

\begin{tabular}{ccccccc}
\hline Metal & $\mathbf{C u}$ & $\mathbf{C r}$ & $\mathbf{P b}$ & $\mathbf{C d}$ & $\mathbf{N i}$ & $\mathbf{F e}$ \\
\hline $\mathrm{EF}$ & 1.17 & 0.84 & 2.31 & 0.88 & 0.86 & 1.00 \\
$\mathrm{CF}$ & 0.47 & 1.25 & 0.45 & 1.20 & 1.22 & 1.05 \\
\hline
\end{tabular}

Table 5.0. Normal and phototoxic levels $(\mu \mathrm{g} / \mathrm{ml})$ of metals in plant bark.

\begin{tabular}{cccc}
\hline Elements & $\begin{array}{c}\text { Normal } \\
\text { range }\end{array}$ & Toxicity range & $\begin{array}{c}\text { Experimental } \\
\text { value }\end{array}$ \\
\hline $\mathrm{Cd}$ & $0.1-24$ & $5-30$ & 0.014 \\
$\mathrm{Cu}$ & $5-10$ & $20-100$ & 0.390 \\
$\mathrm{Cr}$ & $\mathrm{NS}$ & $\mathrm{NS}$ & 0.332 \\
$\mathrm{~Pb}$ & $5-10$ & $30-310$ & 0.276 \\
$\mathrm{Ni}$ & $0.02-5$ & $10-100$ & 0.237 \\
$\mathrm{Mg}$ & $\mathrm{NS}$ & $\mathrm{NS}$ & 7.17 \\
$\mathrm{Fe}$ & $\mathrm{NS}$ & $\mathrm{NS}$ & 1.49 \\
\hline
\end{tabular}

$\mathrm{NS}=$ not stated

Table 6.0. Correlation inefficient matrix of analyzed metals in tree bark samples.

\begin{tabular}{cccccccc}
\hline & $\mathbf{C r}$ & $\mathbf{C u}$ & $\mathbf{P b}$ & $\mathbf{C d}$ & $\mathbf{N i}$ & $\mathbf{F e}$ & $\mathbf{M g}$ \\
\hline $\mathrm{Cd}$ & 1.0 & & & & & & \\
$\mathrm{Cr}$ & -0.3 & 1.0 & & & & & \\
$\mathrm{Cu}$ & 0.2 & 0.2 & 1.0 & & & & \\
$\mathrm{Fe}$ & 0.02 & 0.0004 & 0.6 & 1.0 & & & \\
$\mathrm{~Pb}$ & -0.01 & -0.12 & -0.3 & 0.8 & 1.0 & & \\
$\mathrm{Ni}$ & 0.8 & -0.32 & 0.111 & 0.4 & 0.3 & 1.0 & \\
$\mathrm{Mg}$ & -0.3 & 0.01 & -0.1 & 0.6 & 0.9 & -0.1 & 1.0 \\
\hline
\end{tabular}

\section{References}

[1] E.M.S. Tahawy, R. Hanningan, M. ,Nassef, .and K.A. Ayed, El. (2006). Determination of some heavy metals in the environment of Sadat industrial city. Faculty of science, Cairo University, Egypt. Proceeding of the $2^{\text {nd }}$ environment physics conference,18-22 .pp.145- 151.

[2] United States Department of agriculture (USDA). (2000). Soil Quality -.Heavy metal soil contamination. Urban technical note No 3 .

[3] M. Miranda, M. López-Alonsob, C. Castillob, J. Herna'ndezb, and J.L. Beneditob J.L.(2005). Effect of moderate pollution on toxic and trace metal levels in calves from a polluted area of northern Spain. Environmental
International. $31: 543-548$.

[4] C. Knight, and J. Kaise, (1997). Heavy metals in surface water and stream sediments in Jamaica. Envi. Geochemistry and health, Kingston Jamaica Chapman and hill published,Kingston.19:63-66.

[5] N. E. Okoronkwo, S.A. Odemelam, and A.O Ano.(2006).Levels of Toxic elements in soil of abanoned dumpsite. African Journal of Biotechnology. 5:1241 - 1244.

[6] L. Chimuka and O.O. John (2005). Metals in envirmental media: Study of trace and platinum group metals in Thohoyandou, South Africa. Water S.A. 31: 581-586.

[7] A.M. Gbadebo and O. D. Bamkole. (2007). Analysis of potentially toxic metals in airborne cement dustaround Sagamu, southwest ,Nigeria. Journal of applied science. 7(1):35-40.

[8] J.R. Riordan. (1983). Handling of heavy metals by cultured cells from patients with Menke diseases. In Sarkar, D (eds.) Biological aspects of metals related disease. Raven Press, New York,pp.159 -170.

[9] L.J. Folinbee. (1993). Human effects of air pollution. Environ. Health perspective. 100:45-46.

[10] S. Mishra, S. Srivastava, R.D. Tripathi, R. Kumar, C.S. Seth, and D.K. Gupta. (2006). Lead detoxification by coontail (Ceratophylum demersum L.) involves indication of phytochelatins and antioxidant system in response to its accumulation. Chemosphere 65(6):1027-1039.

[11] O.M. Liu, S. Salmijah, B.S. Ismail and A. Aminah. (2007).The impact of Traffic causing Lead expo-sure to Malaysian school children. Global Jour-nal environmental Research. 1(2):43-48.

[12] T. Kehinde-Phillips. (1992) Ogun State maps. Rex publisher, Ibadan, pp187.

[13] M.E. Omosola and O.S. Adegoke.(1981) Tectonic evolution and cretaceous stratigraphy of the Dahomey Basin. Journal Mineral Geology. 18:130-137.

[14] G. Protano, F. Riccobono and G. Sabatini. Does Salt Intrusion Constitute a mercury contamination risk for coastal fresh water aquifers? Environmental Pollution, 110:51-458.

[15] A.O. Majolagbe, A.A. Kasali and L.O. Ghaniyu.(2001).

[16] Quality assessment of groundwater in the vicinity of dumpsites in Ifo and Lagos, Southwestern Nigeria. Advances in Applied Science Research, 2(1), pp. 289-29.APHA / AWWA / WPCF. 2005. Standard Methods for the Examination of Water and Wastewater. 21st ed. Washington, APHA / AWWA / WPCF.

[17] Department of Environmental (DOE). 1972. Analysis of Raw, Portable and Wastewaters. London, Department of Environmental, 12-16. 
[18] R.A.Sutherland, C.A. Tolosa, F.M.G.Tack and M.G. Verloo. (2000).Characterization of selected element concentration and enrichment ratios in background and anthropogenically impact roadside areas. Arch of environmental contamination and toxicology. 38: (4) $428-438$.

[19] H. Ghrefat and N.Yusuf. (2006). Assessing Mn, Fe, Cu, Zn and Cd pollution in bottom sediments of Wadi Al-Arab Dam, Jordan. Chemosphere. 65: 2114-2121.

[20] G.M.S. Abrahim and R.J. Parker (2008).Assessment of heavy metal enrichment factors and the degree of contamination in marine sediments from Tamaki Estuary, Auckland, New Zealand. Environ. Monit. Assess. 136: 227-238, 2008.

[21] O. Akoto, J.H. Ephraim and G. Darko.(2008).Heavy metal pollution in surface soils in the vicinity of abundant railway servicing workshop in Kumasi, Ghana. Int. J. Environ. Res. 2(4): 359-364, 2008.

[22] United States Environmental Protection Agency, USEPA. (1982).Aquatic Fate process Data for Organic priority pollutant. Office of Water regulation and Standards. Washington, DC 20460.

[23] H.M. Ragunath. Groundwater. (1987).New Delhi, Wiley Eastern Ltd., p. 563.

[24] M. Coetsiers and K. Walraevens. (2006). Chemical characterization of the Neogene Aquifer, Belgium. Hydrogeology. 14: 1556-1568.
[25] O.S. Fatoki, Z. Mbolekwa and O.R. Awofolu (2004). Levels of trace metals in water and sediment from Tyume River and its effects on an irrigated farmland. Alice, South Africa. Water S.A. 31: 87.

[26] S. Ogunyemi, O. R. Awodoyin and T Opadeji. (2003). Urban Agricultural Production: Heavy Metal and multivariate assessment of contamination sources. Chemosphere 74: $491-495$.

[27] A.A. Amusan, D.V. Ige and R. Olawale. (2005). Characteristics of soils and Crops uptake of metals in Municipal waste dumpsites in Nigeria. J. Hum. Ecol. 17(3):167 - 171

[28] P. Jarmo (2001).Heavy metals loading in tree barks, Mossses and Lichen Forest condition in a changing environment. The Finnish case study, t the Finnish forest research institute, Oulu, Finland. Forest sciences. 65:16.

[29] A.O. Bowen (1979). Normal and Phytotoxic level of metals in plants leaves and barks. Journal of Environment quality.7: 27.

[30] World Health Organization (WHO). 2006. Guidelines for Drinking-Water Quality. First addendum to 3rd ed. 1, Recommendation. J. Hydrol Geneva, WHO (World Health Organization), p. 595.

[31] National Guidelines and Standards Drinking Water Quality. (2005) NESREA Publications, Federal Ministry of the Environment 5 (3) :54. 